Athens Journal of Mass Media and Communications

Volume 7, Issue 4, October 2021 - Pages 257-280

\title{
New Media in Film Distribution in Bangladesh: Bane or Boon?
}

\begin{abstract}
By Saiyeed Shahjada Al Kareem*
The research explores the little-understood phenomena of new media based film distribution system in Bangladesh, finds the consequences of new media in film distribution, and makes a recommendation for developing an effective film distribution system. This research employs a qualitative approach where indepth interviews of people involved in traditional and online film distribution systems are taken to collect data. The study finds that new media based film distribution is an emerging sector in Bangladesh, and it will strengthen the overall distribution system by reducing the distribution costs and increasing revenue.
\end{abstract}

Keywords: new media, internet, online, film distribution, video on demand

\section{Introduction}

This research explores the utilization of new media in film distribution in Bangladesh, finds the consequences of new media-based film distribution and searches for ways to establish an effective film distribution system based on new media.

The process by which "a film reaches the marketplace and is made available to its target audience" is called film distribution, which is done by selling a film to different gateways like theatrical distributors, broadcast networks, DVD companies, and new-media outlets (Parks, 2007, p. 1). In this process, fixing release dates and launching advertising campaigns are also done by the distributors (Bordwell and Thompson, 2008, p. 36).

The film distribution system of Bangladesh is going through a crisis at the present time. The digital era has caused the industry to experience varying problems. The emergence of new media has raised a question that invites us to think about reorganizing the distribution system. According to Neese (2016), social media, blogs, video games, and online news outlets are typically referred to as "new media" and these channels of communication have far-reaching implications for society, business, and politics. Different terms like digital, interactive, hypertextual, virtual, networked, and simulated, define new media (Lister et al., 2009, p. 13). The popular culture of new media has been started with the video games (Lister et al., 2009, p. 237) whereas the term "new media" refers to the "Internet" and also a virtual environment, digital TV or blog (Lister et al., 2009, p. 12). Again, "Internet" is defined as the collection of networks that links computers and servers together (Lister et al., 2009, p. 164).

\footnotetext{
*Lecturer, Department of Television, Film and Photography, University of Dhaka, Bangladesh.
} 
In recent times, the conventional movie distribution system has been modified throughout the entire globe after the upward push of new media, which are the sort of media that might be native to computer systems, computational and rely on computers and the internet for distribution, such as: YouTube, Netflix, Amazon and so forth. The film distribution system of Bangladesh is also going through changes as new media is being utilized in it, but these changes are mostly an unexplored area as academics have still not looked into them through a critical lens. As Cunningham et al. (2010) argue that Online Distribution benefits idependent and the rest-of-the-world cinema (Cunningham et al., 2010, p. 128), where online refers to the new media, it is essential to learn about the present state of online film distribution in Bangladesh to analyze the impacts of it on the whole distribution system.

Currenly, there are three companies: Bongo, Bioscope, and Iflix that are distributing feature films along with other video content in Bangladesh. Bongo was the first VOD (Video On Demand) platform of the country that started streaming in 2012 (M. Rahman, personal communication, May 8, 2018). Bioscope was launched in 2016 as a value-added service of Grameenphone, a leading mobile service operator in Bangladesh. Moreover, Grameenphone itself is supported by Telenor, a Norwegian multinational telecommunications company (M. Rahman, personal communication, May 8, 2018). Iflix is a multinational VOD streaming site that started its journey in Bangladesh in 2017. It is supported by the leading telecommunications group Axiata, a conglomerate originating in Malaysia and by Robi Axiata Limited in Bangladesh (S.R. Islam, personal communication, May 8, 2018). Two companies named Khona Talkies and Indi Minds distribute Bangladeshi short and feature films to different international film festivals. Khona Talkies started distribution in 2011 (A. Rakhine, personal communication, May 12, 2018) and Indi Minds in 2016 (S. K Paul, personal communication, March 1, 2018).

This study investigates the little-understood phenomena, that is, the use of new media for distributing films and strives to find out the impacts of new media in the film distribution system with a view to finding ways to develop an effective film distribution system in Bangladesh.

\section{Significance of the Study}

In Bangladesh, the entire film industry is facing different kinds of issues. Film distribution is also facing problems as the system is not able to generate enough revenue in return of the money invested by producers. The monopoly of booking agents has made distributors fall into great problems while distributing films (Khan, 2017, p. 79). However, the proper distribution system can be a remedy to this problem, and the utilization of new media in film distribution can be the trump card to turn the least active distribution system into an effective one. For this reason, the present situation of new media based film distribution in Bangladesh needs to be explored to understand the impacts of new media on the overall film distribution process. It will also provide suggestions to establish an effective distribution system utilizing new media. 


\section{Literature Review}

This section aims to assess the essential scholarly works on new media based film distribution. The key arguments, methodologies, and limitations of these studies are discussed to comprehend the current trends in this field of study and find out the gaps. Since no work is found on new media based film distribution in Bangladesh, research work in related fields are examined here.

\section{Traditional Film Distribution}

In the book "Film Art: An Introduction", Bordwell and Thompson (2008) discuss the film distribution process, explain that it is done mainly by the distribution companies, which they say, form the core of the economic power in the commercial film industry. Traditional film distribution refers to the theatrical release of the films, as in, distribution companies make films available to different exhibiting theatres for the audience. For this reason, a large amount of money goes into distributing films. Bordwell and Thompson (2008) estimate that, for Hollywood films, the average cost of production is $\$ 60$ million and for distribution, it is $\$ 35$ million (Bordwell and Thompson, 2008, p. 36). They also describe the two major strategies of theatrical distribution. In platforming strategy, the film is first released in few big cities and then gradually around the rest of the country according to the performance of the film. In wide release strategy, a film is released in many cities and towns and also overseas (Bordwell and Thompson, 2008, p. 36). A theatre is provided a little percentage of the gross money as the authors assert that, in the first week, a theatre gets only $10 \%$ from the gross amount of money; in the United States, the distributor, takes $35 \%$ of the rentals as distribution fee and rest are for the filmmaker (Bordwell and Thompson, 2008, p. 34-35).

\section{Online Film Distribution}

Nowadays, with the advancement of the internet, cyberspace has become a new platform for film distribution, which Bordwell and Thompson (2008) state to be the new frontier of video distribution, and regard this as online film distribution (Bordwell and Thompson, 2008, p. 38). It has emerged since that it is possible to release any length of film online, and a huge profit can be gained with the advantage of blocking the films from being pirated (Bordwell and Thompson, 2008, p. 38).

Cunningham et al. (2010) have conducted a study on the film industry of Australia, where they have done an online search and examined the content and business models of websites that deliver movies on demand through the internet. They have consulted leading trade magazines, online business directories, expert service providers, and used business databases, such as Factiva and Proquest, to identify relevant articles on the industry and on OLD (On Line Distribution) service providers. In their research, they discuss how OLD first came into the sector and made changes in the film industry and how it works as a disruptive technology in the film industry. 
According to Cunningham et al. (2010), online distribution (OLD) first emerged in 1997 in North America with pioneers like I-Film, Atom Films, Intertainer, SightSound, Pop.com, CinemaNow etc., but these companies had been absorbed by larger companies as they failed to establish sustainable business models (Cunningham et al., 2010, p. 121). Paramount, Universal, Warner Brothers, $20^{\text {th }}$ Century Fox, Walt Disney, and Sony - the six major Hollywood studios had invested in Movielink and Movie beam in 2001 which were expected, they state, to be the leaders of a second wave but both websites were sold in 2006 (Cunningham et al., p. 121). Apple iTunes led a third wave by building a leading movie download business with Hulu, at the same time as Netflix, Blockbuster Amazon, and some others (Cunningham et al., 2010, p. 121). Amazon came with its own VOD service Unbox, and Netflix made available its streaming service 'Watch Instantly' to its DVD subscribers in the United States in 2006 (Cunningham et al., 2010, p. 123). Via its Australian online store, Apple iTunes launched its movieson-demand service in 2008 (as cited in Cunningham et al., 2010, p. 124).

Advertiser supported site Hulu started live streaming in March 2008 and within a year, became five times bigger than how it was when it started out. However, Hulu, which had 2.4 percent share of the total OLD market, was dominated by YouTube, which had a 41 percent share (Cunningham et al., 2010, p. 122). However, the majority of the YouTube video content did not attract advertisers as most of the videos on the site were user-generated, and this caused YouTube to face a 470 million dollar loss in 2009 (Cunningham et al., 2010, p. 122). In 2009, Hulu's advertiser-supported free viewing business model, may have seemed unsustainable as ad revenue of online video was estimated to be 60 percent lower than that of the same program shown on network television. This led Hulu towards a subscription-plus-advertising revenue structure (Cunningham et al., 2010, pp. 122-123). Different experiments like Warner Bros. studio's attempt in digitally renting movies on Facebook in 2011, made Marble, CEO of an online marketplace, to estimate in 2012 that the online distribution had become very vital for major Hollywood Studios (Kozlowski, 2012)

\section{Film Distribution in Bangladesh}

In Bangladesh, most of the film distributors are also the producers at the same time, and there is only one association for them named "Bangladesh Film Producers and Distributors Association". There are booking agents who work as middlemen between the distributors and exhibitors, and they control the whole system since they are the authority to decide which film will be exhibited where. Hossain (2017) states this as a "weird situation" and this situation predominates the film industry.

Kareem (2017), in his research, has explored the film distribution process and its problems in Bangladesh, where he interviews eight traditional film distributors and used inductive thematic analysis to analyze the qualitative data. He stated that in most cases, the same person acts as the producer and distributor of a film, but in the case of different people taking on these two roles, a distributor is to be paid $15 \%$ of the net profit. He adds that distributors distribute the films among the 
exhibiting halls with the help of booking agents who are the mediators between distributors and exhibitors. Booking agents book films for the exhibiting halls and also take a $10 \%$ commission of net income from the distributors. Exhibiting halls allocate payment in three ways, fixed rental, minimum guarantee, and percentage or share money. The method "percentage" or "share money", in which the distributor collects a fixed percentage of net income, is the worst one, as Khan (2017) shows that through this method, a producer gets only $20 \%$ of a ticket's price (Khan, 2017, p. 77).

Since the exhibitors do not have the advanced technological support to exhibit digital films, some organizations are taking advantage by providing poor quality projection support and controlling the exhibiting halls (Khan, 2017, p. 77). In his research, Ahsan (2016) has taken face to face interviews of film industry professionals of Bangladesh and stated that an organization named Jaaz Multimedia has evolved as an intermediary force in the film industry of the country, and is charging money from the digital film producers to let them use the digital film projectors in the exhibiting halls (Ahsan, 2016, p. 244). This is a threat to the film industry as Parvez (2013) states that this tendency to control the film exhibition system can make cinema lose its independence, which is what happened in Canada and Australia when six big American companies had taken control over the entire film distribution system in the 1970s and 1980s (Parvez 2013, p. 6).

\section{Impacts of New Media on Film Distribution}

In their research, Kehoe and Mateer (2015) have done a situational case study on the film industry of the United Kingdom and examined two movements impacting the industry where new media have made changes in consumption habits, leading to the emergence of new business models. The Value Chain concept was coined by Porter in 1985, where "value chain" is a framework for identifying the set of interconnected value-creating activities performed by a company in developing, manufacturing, delivering, and supporting its product and the points of connection with the activities of suppliers, channels, and customers. Digital technology affects the motion picture value chain by bringing a new type of consumers named "active audiences" into play. Kehoe and Mateer (2015) define "active audiences" as a group of consumers who have knowledge of technology, and consume media products through the internet. Kevin Zhu led a reasearch with its theoretical foundation based on the economics of digital goods and transformation of industry structure. With Figure 1, Zhu (2001) has shown how internet-based distribution can affect the value chain as the internet tends to disintermediate the traditional distribution agencies (p. 275). He also argues that internet-based film distribution will reduce the distribution cost, and the importance of traditional distributors will decrease (Zhu, 2001, p. 275). 
Figure 1. The Motion Picture Value Chain

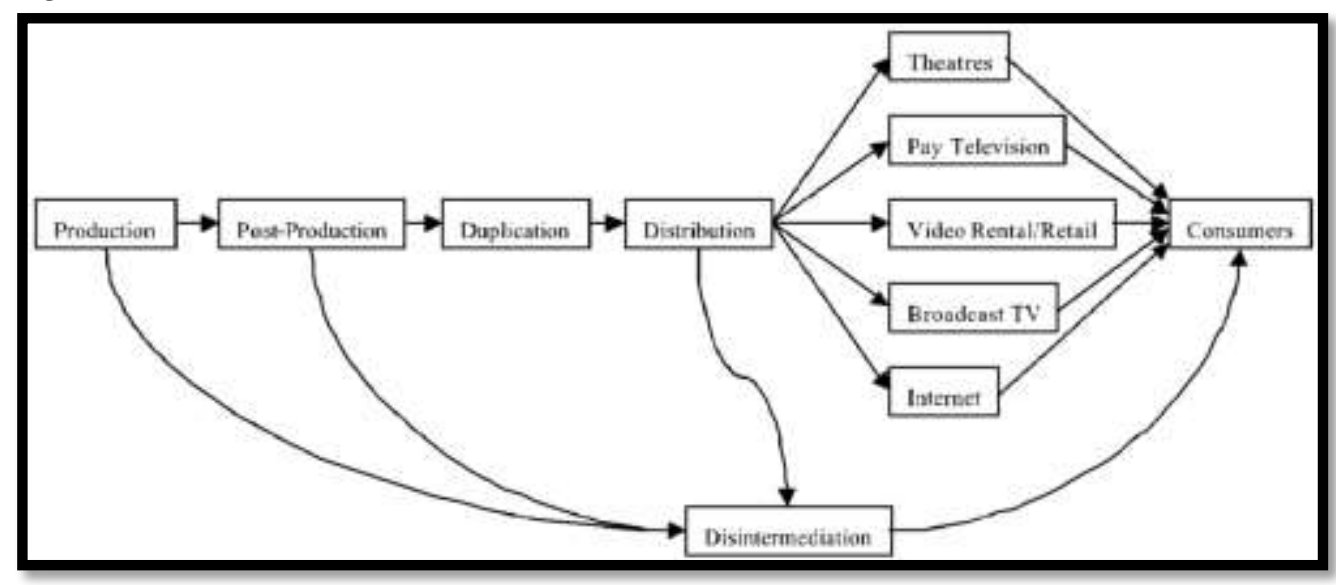

Source: Zhu, 2001, p. 275.

Kehoe and Mateer (2015) also discuss how changes in business models occur while distributing films through new media. They explain that multiple approaches have emerged, such as "ultra VOD" and "day-and-date" releases. "Ultra VOD" refers to releasing a cinema online through transactional video on demand (TVOD) a week before scheduled theatrical release to create a sense of exclusivity and "day-and-date" means a concurrent release on the same day on multiple distribution platforms like cinema theatres, online VODs (Netflix, others), DVDs, etc. (Kehoe \& Mateer, p. 102). There is an advertiser supported model that enables visitors to watch movies and TV programs for free, whereas this sales model can offer charges, which are subscription sites that take rental for the determined time period (Cunningham et al., 2010, p. 126). Again, there is an IT-innovation model where platforms like Hulu are content-driven, and services like iTunes are devicedriven. This means a consumer needs to own an iPod, Apple TV, iPad or a supported device which Cunningham et al. (2010) states as a significant disruption to standard business models because it sells premium or near-premium content intending to make a profit from hardware device sales and to buy market share (Cunningham et al. 2010, pp. 126-127).

Ahmed (2010), in his research, employed case studies on three Bollywood movies, which include Om Shanti Om (2007), Ghajini (2008), and Dev. D (2009), to understand how new media tools were used in their marketing strategy. He found that, opposing traditional media, the internet is dominating the viewers's decision-making process about which film to watch. Nime (2012), in his Ph.D. thesis, employed a qualitative method, and in an exploratory way, tried to understand the impact of digital technologies upon the culture and economy of documentary distribution. He argues that online distribution not only makes the films available to the audience but also attaches the audience in the distribution process. He states that online distribution platforms like Netflix, YouTube etc. attach consumers by including systems of rating, commenting, sharing, tagging etc., which help them get more audience.

Researchers have discussed new media based film distribution around the world. However, from a Bangladeshi perspective, its role on Bangladeshi film 
distribution has been left mostly unexplored by the researchers. Ahsan (2016) has identified the rise of an intermediary force as a problem, which is trying to control the film distribution system, but his research did not provide any suggestion to resolve the problem. Kareem (2017) has outlined the traditional distribution system in Bangladesh and stated that a server-based digital distribution system is yet to be developed in Bangladesh. However, there is no insight in his research about the utilization of new media in the distribution system active at present.

In different researches, Kehoe and Mateer (2015), Zhu (2001), Fair (2006), Ahmed (2010), and Nime (2012) tried to understand the impacts of new media based film distribution in the worldwide perspective. However, it does not seem enough to paint a full picture, and no research has yet been done to understand the effects of new media based film distribution in Bangladesh.

\section{Research Questions}

The literature review suggests that the following research questions should be explored in the present research.

RQ-1: How have the new media been utilized in film distribution in Bangladesh?

RQ-2: How will the new media affect the film distribution in Bangladesh?

RQ-3: How can an effective film distribution system be created in Bangladesh based on the new media?

\section{Theoretical Framework}

The research takes the critical political economy of communication as the theoretical base to identify the dominant economic and political factors in the utilization of new media and its effect on film distribution in Bangladesh. Mosco (2009) has defined critical political economy as "the study of social relations, particularly the power relations that mutually constitute the production, distribution, and consumption of resources" (Mosco, 2009, p. 24). Thomas Guback, in his essay "Are We Looking at the Right Things in Film", first drew attention on the study of cinema from a political-economic approach in 1978. He argued that film studies did not pay attention to the analysis of cinema as an economic institution and his use of institutional approach to film seemed more like a political-economic approach to the study of communication (Wasko, 2004, p. 219).

The relationships between media power and state power are analyzed in the discussion of the critical political economy by identifying the owners and controllers of media and communication resources (Wasko, 2014, p. 260). In the case of film distribution, the owners and controllers of new distribution outlets, relations between the state and the distributors are examined by the critical political economy. Furthermore, media power is assessed by the discussion of class issues (Wasko, 2014, p. 263). Critical political economists ask if online film 
distribution is open for all or bound to a separate class. On the other hand, the critical political economy of new media should be concerned with the understanding of power structure, its evolution, and renewal (Mansell, 2004, p. 6), where understanding the domination of small capital by big capital and capturing the market by big conglomerates are discussed. The involvement of the state in the film industry, reproduction of power structure, uneven power distribution, and wealth, which are represented by the industry, are also matters of interest in the critical political economic approach (Wasko, 2004, p. 228).

Drawing on the work of Murdock and Golding (2005), Mosco (2009) discussed four cornerstones of the critical political economy: social change and history, social totality, moral philosophy, and praxis. Social change and history refer to examining dynamic forces within capitalism to understand the change in social relationships over time (Mosco, 2009, p. 3). Guback (1969) and Pendakur (1990) tried to understand the film industries from historical perspectives where Mansell (2004) finds internet as new media involving a significant change in social and economic relations. Exploring the history of new media based film distribution will help to understand the problems of traditional film distribution and the circumstances which made way for the new technology in the film distribution in Bangladesh. The growth of new media technology can be understood by the analysis of policies and politics, which surround the digitization process (Wasko, 2014, p. 267). In the case of film distribution where online distribution is not bound to a specific border because of its transborder nature, local culture is being affected by the global culture, which is also examined by the political economists.

Social totality suggests understanding society with a holistic approach from economic, political, social, and cultural perspectives (Mosco, 2009, p. 3). According to Wasko (2004), it studies the relationship among institutions, social relations, commodities and hegemony (Wasko, 2004, p. 222). It asks to understand the connections between the political and economic (Mosco, 2009, p. 329) where with the help of government policies, privatization and liberalization, the free market is created. The growth of multinational capital throughout the world has led to the development of many new centers of media production and has changed the direction of global and regional flows of media materials (Bhuiyan, 2002). Big foreign conglomerates as well as local companies have started online film distribution in Bangladesh, which has caused a change in the media flow where media materials like cinema are spreading from developing to developed areas of the globe.

Moral philosophy refers to the analysis of the economic system with the discussion of normative and moral issues (Wasko, 2004, p. 222) like 'justice, equity, and the public good' (Mosco, 2009, p. 32). Political economists emphasize understanding whether the public has access to goods equally or those which are commodified, where commodification transforms goods and services which are valued by their earning in the marketplace as communication technologies and contribute to the primary commodification process in the society (Mosco, 2009, p. 11). Internet accelerates the opportunities for commodification by increasing chances to measure and monitor (Mosco, 2009, p. 12), as in the case of online film 
distribution, more control comes over the distribution process as the subscribers and the subscription fees are definite. Again, commodification is intensified by spatialization. Mosco (2009) described spatialization as "the process of overcoming the constraints of space in social life" (Mosco, 2009, p. 14). Harvey (1989) identifies "time-space compression" refering to the way that the world is becoming smaller (Harvey, 1989, p. 147), as communication and information technologies promote flexibility and control throughout the industry (Mosco, 2009, p. 14) and thus encompasses the process of globalization. Praxis is referred to as free and creative activities to change the world with actions (Mosco, 2009, pp. 34-35) "to transcend the distinction between research and policy" (Wasko, p. 223).

This political-economic approach is used to understand the new media based film distribution by inquiring about the purpose of using new technology. It helps to ask why new media technology is used in film distribution and who benefits from this? By taking a historical approach, this research explores why and in what context internet technologies have been used in film distribution in Bangladesh, what its consequences are and strives to identify its beneficiaries and those who suffer losses.

\section{Methodology}

This study employs a qualitative research method. It utilizes in-depth interviews to collect data. As the study focuses on exploring new media based film distribution in Bangladesh and finding out the effects on traditional film distribution with a view to establishing new media based film distribution, people who are involved in film distribution, both traditional and online, make up the population of this research.

The only global video on demand (VOD) service provider in Bangladesh is Iflix, which has just started its journey in this country with the support of Robi Axiata Limited, a mobile network operator (S. K Paul, personal communication, March 1, 2018). Bioscope is another video streaming platform supported by Grameenphone, a telecommunications company (S. K Paul, personal communication, March 1, 2018). There is a Bangladeshi online VOD service provider named BongoBD (S. K Paul, personal communication, March 1, 2018). There are also some independent online distribution agencies such as Khona Talkies, IndieMinds Inc., who distribute short films made by Bangladeshi filmmakers to different festivals worldwide (S. K Paul, personal communication, March 1, 2018). On this note, it is relevant to mention that there are 219 enlisted members of the Bangladesh Film Producers and Distributors Association (Bangladesh Film Producers and Distributors Association, 2018).

Interviewees are selected specifically based on their involvement with the film distribution process. Ten film distribution companies have been selected as the sample. Among them, six are traditional film distribution companies randomly selected from the various companies that employ the 219 members of Bangladesh Film Producers and Distributors Association, and four are online distribution companies. In-depth interviews of the ten respondents of the following ten 
distribution companies have been taken to collect detailed information. Among them, four respondents are from four online distribution companies, who have been interviewed to understand the present situation of new media based film distribution in Bangladesh. The other six respondents are from six traditional distribution companies and have been interviewed to determine the impacts of new media based film distribution on traditional film distribution. All ten respondents who have been interviewed were asked to give suggestions for creating an effective film distribution system. All the questions were open-ended, and the respondents were encouraged to answer in detail. Follow up questions were asked based on the reply of the respondents.

Table 1. Interviewees (Online Film Distributors)

\begin{tabular}{|l|c|c|c|}
\hline Category & $\begin{array}{c}\text { Name of the } \\
\text { Company }\end{array}$ & $\begin{array}{c}\text { Name of the } \\
\text { Respondent }\end{array}$ & Designation \\
\hline Feature Film & BongoBD & Mushfiqur Rahman & $\begin{array}{c}\text { Director, Content } \\
\text { Acquisitions }\end{array}$ \\
\hline Feature Film & Iflix & Sheikh Rifat Islam & $\begin{array}{c}\text { Head of Marketing, } \\
\text { Bangladesh \& Nepal }\end{array}$ \\
\hline Short Film & IndieMinds Inc. & Shubh Kumar Paul & Distributor and owner \\
\hline Short Film & Khona Talkies & Aung Rakhine & Director \\
\hline
\end{tabular}

Table 2. Interviewees (Traditional Film Distributors)

\begin{tabular}{|c|c|c|c|}
\hline Category & $\begin{array}{l}\text { Name of the } \\
\text { Company }\end{array}$ & $\begin{array}{l}\text { Name of the } \\
\text { Respondent }\end{array}$ & Designation \\
\hline Feature Film & $\begin{array}{c}\text { Ashirbad } \\
\text { Chalacchitro }\end{array}$ & Razib Ahsan & Executive Director \\
\hline Feature Film & Janani Kothachitra & Sajjad Hossain & Distributor and Owner \\
\hline Feature Film & Jazz Multimedia & Abdul Aziz & Chairman \\
\hline Feature Film & Tushar Kathachitra & Abdul Mabud Kawsar & Distributor and Owner \\
\hline Feature Film & $\begin{array}{c}\text { Malancha } \\
\text { Chalacchitro }\end{array}$ & Miah Alauddin & Distributor and Owner \\
\hline Feature Film & Modhumita Movies & $\begin{array}{l}\text { Iftekhar Uddin } \\
\text { Nowshad }\end{array}$ & Distributor and Owner \\
\hline
\end{tabular}

Consents of the respondents were taken before recording the interviews. A voice recorder was used to record the interviews of the respondents. After that, the interviews are transcribed verbatim. Inductive thematic analysis was adopted to analyze the in-depth interviews. Transcribed interviews have been coded and divided into thirteen themes based on the three research questions and then analyzed according to the themes.

\section{Results}

Online film distribution is an emerging sector in the film industry of Bangladesh. It has not yet become a primary distribution medium but it is developing to become the secondary distribution outlet. 


\section{New Media Distribution Process}

There are two types of online distribution platforms in Bangladesh, feature film distribution platforms and festival distribution platforms. Three companies release feature films online, and two companies distribute short and feature films to international film festivals through the internet. Different companies employ different strategies for this distribution. Originating in Bangladesh, Bongo is an emerging multinational video on demand streaming site, which is now streaming in five South Asian countries: India, Pakistan, Sri Lanka, Nepal, and Bangladesh. It is planning to start streaming in another 31 countries, targeting Bangladeshi and native audiences especially who speak in Bengali. In Bangladesh, Bongo is streaming with the name BongoBD.

To start streaming videos, Bongo applied for a publishing license to the organization MCN (Multi Channel Network), which provides support to the online video streaming sites. After procuring the license, it became authorized to launch the streaming site. BongoBD started acquiring online distribution rights of different video content as well as films from the owners based on two payment processes, royalty and onetime payment. BongoBD is different from other streaming sites as it acquires complete distribution rights, which allows it to release the content not only on BongoBD but also on other platforms as it wishes. To protect the content copyright, BongoBD created a YouTube channel where the content management panel (CMS) provided by MCN allowed it to block the same video content owned by BongoBD from being uploaded on other YouTube channels.

It uploaded all the video content on the YouTube channel but kept it on private mode to create a demand for the content, with a view to starting a subscription-based platform. The company wanted to create more demand by keeping the video content in private mode for a long time but could not continue as some other companies started buying online rights of different video content published those on their YouTube channels. This created a pressure on BongoBD to publish their video content. However, BongoBD faced a problem in finding a suitable payment method to start a subscription-based streaming service. There is no common payment gateway for the subscribers in Bangladesh since very few people use credit cards here.

By this time, Grameenphone started Bioscope - a video on demand streaming service, and BongoBD allied with it by providing content and logistic support. Bioscope is currently providing free service and will later go for the subscription model. Bioscope streams the latest feature films along with other video content like music videoes, lifestyle content, drama, live television channels etc. BongoBD will support Bioscope for a certain period of time. The platform is preparing itself by collecting video content for a big startup as it already has a thousand feature films and various other types of content. It wants to start as a leading VOD streaming service in Bangladesh using Grameenphone as the payment gateway. BongoBD wants to emerge as a streaming site like Amazon or Netflix and plans to stream BongoBD Originals, which means, it will start streaming self-produced content at one point. 
Originating in Malaysia, Iflix is a multinational streaming site which recently started its journey in Bangladesh. Iflix focuses on building a market in emerging economic countries where Netflix is not prominent yet. The respondent remarks,

"Iflix is working in emerging South Asian markets like Bangladesh, Nepal, Maldives, Sri Lanka and in Malaysia, Thailand, Singapore, Indonesia, Philippines apart from big markets like India where Netflix has huge investment..." (S.R. Islam, personal communication, May 8, 2018.)

Iflix releases the latest Bangladeshi feature films after their theatrical release. In a very short time, Bangladesh has become the fourth most important country for Iflix, placing next to the top three countries, Malaysia, the Philippines, and Indonesia. It has started as the designated video platform of the telecommunications company Robi Axiata Limited. It seems to be a trend for every telecommunications company to try to provide a video platform as a value-added service nowadays. On the other hand, Iflix attached itself to Axiata after signing a contract that entails the platform to work in the countries where Axiata provides telecommunications services. This will solve an important issue as the telecommunications service itself will work as the payment gateway for the subscribers just as Grameenphone will function as a payment gateway for BongoBD. Robi is at an advantage here as Robi users will be able to watch Iflix content at a lower price than other telecom service users as Robi can design their data package offers by linking Iflix services.

Unlike Bongo, Iflix buys only the online rights of the content. In case of feature films, Iflix buys the online rights to release the films on its platform after the theatre release. Iflix releases Iflix Originals in other countries and is now planning to produce Iflix Originals in Bangladesh as well. It plans on introducing two systems to earn revenue, which are: the free tier, and the premium tier. The free tire will be advertiser-supported, and the premium tier will be subscription fee based. Content owners will be paid with the off-the-shelf (OTS) model, where they will get a specific amount of money for per hour view of the distinct amount of content. For example, in case of royalty, if someone provides 20 films to Iflix, $50 \%$ of the revenues from per hour view of the 20 films will be provided to the owner.

Khona Talkies and Indi Minds distribute short and feature films to different international film festivals. Khona Talkies also tries to distribute films to movie theatres after festival distribution and later to online platforms. It mainly focuses on alternative cinemas which are not well received in movie theatres. With this, it encourages promising film directors of the country by creating a demand for Bangladeshi films in the festival-oriented markets of the world. Indi Minds also distributes films to the festivals and helps the filmmakers aware of the rules and regulations of participating in international film festivals.

\section{Reasons behind the Emergence of Online Film Distribution}

There are four reasons that are vital to the emergence of online-based film distribution in Bangladesh. Firstly, the business of CDs and DVDs has been 
destroyed by the rise of piracy in 2006-2007 as video content were copied from DVD and uploaded on online sites. According to one of the respondents,

"In the mid-2000s, mainly in 2006 and 2007, it was found that the business of CDDVD is not very profitable as their content became available to all because of piracy" (M. Rahman, personal communication, May 8, 2018.)

As a result, a massive demand for video content had emerged in Bangladesh, but there were no streaming sites to meet that demand at all. In this situation, the active streaming sites have been lauched with a view to capturing the market.

Secondly, the number of movie theatres have decreased from around 1,200 (Hayder, 2012) to 321 (Roy, 2016) in the last decade. The environment of the theatres that are still exhibiting films is not suitable for all kinds of audiences. On the other hand, the content of the cinemas in the last decades did not satisfy the audience, and this played a role in making the audience averse to watching films in theatres. But most people were still interested in films and were searching for a way to watch films without going to theatres. Again, in case of big cities like Dhaka, Chittagong, the theatre-going audience is bound to sacrifice extra time while commuting to the theatre due to traffic jam. These conditions amplified the need for VOD streaming services, which attracted the online distributors.

Thirdly, there are audiences for Bangladeshi content in different countries of the world, especially the people working in different foreign countries who want to watch Bangladeshi content. This was also one of the reasons behind launching multinational VOD streaming platforms.

Fourthly, an online film distributor needs to spend a minimal amount of money to distribute films. On the other hand, profit raising is a slow process but not limited, unlike the onetime profit from the theatres. For example, a standard film produced with 1 crore Tk may earn 80 lac from the theatres, 20 lac from television rights, and another $20 \mathrm{lac}$ Tk from online rights. But in case of royalty based contracts, the income from online distribution may exceed 20 lac, depending on the number of hours the film was viewed for. This has made the content makers gain interest in online distribution.

Moreover, different companies that emerged to distribute films to film festivals have three reasons that contributed to their emergence. Firstly, independent cinema is not very popular in Bangladesh as they cannot gather much of the audience attention because it is alternative in content and presentation compared to the mainstream films. This is supported by a comment from one of the distributors who stated,

"Most of the audiences in Bangladesh are not yet ready to watch these kinds of films" (A. Rakhine, personal communication, May 12, 2018.)

As a result, these independent cinemas are not welcomed by traditional distributors for theatre release. For example, The Unnamed (2016), Kingdom of Clay Subjects (2016), Halda (2017), all of these critically acclaimed films were released in very few theatres because of their alternative nature. So, production and distribution organizations like Khona Talkies came forward to help in making 
and distributing these kinds of films to different foreign film festivals through the internet, where these are screened and critiqued.

Secondly, submitting films in foreign festivals is quite difficult, which is true for both feature and short films. Film submission needs to go through a rigorous and complicated process as many formalities with massive paperwork and a great experience is required. Some festivals ask to see "working stills" as in, photos that were taken during the film's shooting process. Again, they require a "logline" for the film, which describes the whole film in only one sentence. In some cases, film festivals demand a press release or press kit about the film. But in most cases, the filmmakers are not familiar with these formalities, which led companies like Khona Talkies and Indi Minds to come forward and take over as festival distributors.

Thirdly, in case of Indi Minds, it came into the market of festival distribution with a plan to become renowned as a festival distributor, which is vital for the career of the distributor in many ways. Distributing some good films creates a good track record for the distributor and contributes to developing the reputation of a distributor. To submit films, a fee needs to be paid; however, a reputed distributor with a good track record may get a certain percentage of discount and in some cases, be allowed to submit films completely free of charge. Again, very few festivals invite short filmmakers to the festival while providing full support, which includes air fare, lodging, food expenses etc. but a reputed distributor can manage full support for the director of the film. Moreover, the distributor of Indi Minds is developing a worldwide network with other distributors by distributes short films, with the intention of establishing a platform for short films in Bangladesh similar to that of the television channel "ShortsTV" in America.

\section{Challenges to the Online Film Distribution}

Distributors face various kinds of problems, as online film distribution is still a developing sector in Bangladesh. Firstly, most of the content makers are not interested in online distribution as they do not yet understand the way it works. Some relate it to piracy. Secondly, some content makers are not aware of copyright laws. Sometimes they use copyrighted music as the background score of their content. As a result, the content gets blocked with the claim of the owner of the music when uploaded on an online site. Therefore, distributors have to be very thorough to know the credibility of the content, but this easier said than done. The distributors are not well equipped enough to detect the copyrighted items in the contents before uploading. Thirdly, internet speed and costs are also vital concerns for online distributors. Slow internet speed costs more money if anyone wants to watch a film on a mobile phone using their telecommunications service provider as a payment gateway. For example, if it takes around one gigabyte of data (that would have to be bought separately from the telecom network provider) to watch a film, that costs at least 35-40 taka, and this makes it slightly expensive for the audience of Bangladesh. Fourthly, festival distributors face problems when they find films which do not meet the festival requirements as filmmakers are not aware of the different kinds of requirements of the festivals. 
The telecommunications companies mostly occupy the emerging new media based film distribution sector of Bangladesh, as most of the streaming sites have been launched as value-added services of different telecommunications companies. As the sector has only just started to grow, it is contending with different kinds of problems at present.

\section{Online Film Distribution: Blessing or Threat?}

As online film distribution is a new concept in Bangladesh, some traditional distributors are not yet familiar with the processes that are involved. They are confused with the new type of film distribution and think that the consequences of online film distribution will be revealed by the way the capital invested on the films is recovered. There are different opinions among the distributors about the consequences of online film distribution. Some think online distribution will affect traditional film distribution by reducing the number of theatre-goers. If films can be found and watched online, people will lose interest in going to the theatres. As a result, the number of exhibiting halls will decrease, and thus theatre releases will be affected.

Most traditional distributors hardly face any challenge because of online distribution. They argue that online distribution is still a developing medium in Bangladesh. Only a few movies have been released online after their theatre release. It has not yet become the primary platform for distribution. Here, it is almost a secondary, sometimes tertiary platform as people still prefer watching films in theatres and will always do so if only a better environment is ensured in the theatres. Again, they believe that online distribution will strengthen the film distribution system in its entirety, because the potential revenue to be earned is unlimited here as it depends on the overall watch-time of the online audience. Additionally, online film distribution will reduce the cost of distribution, removing the intermediaries of the traditional film distribution process. There will be no need for the middlemen, such as booking agents and exhibitors, since the film will reach the audience directly from the distributor through the internet.

\section{Suggestions for Developing an Effective Film Distribution System}

Distributors suggested taking different steps to create an effective film distribution system based on new media. However, they also emphasized that it is impossible to create an effective film distribution system based only on new media. There needs to be coordination between traditional and online distribution as traditional distribution is still the primary distribution medium in Bangladesh. To increase content makers' interest towards online distribution, distributors need to make them understand the details of online distribution processes. In case of giving online distribution rights to the distributors, some content makers believe in revenue sharing, and others are interested in the onetime payment method. The revenue sharing method must be explained to them in a credible way. Again, content makers need to be made aware of copyright claims by arranging different kinds of workshops and training. In addition, proper logistic support must be 
provided to detect the copyrighted items in the content before uploading said content on online platforms. Moreover, the data costs need to be reduced and highspeed internet should be ensured to push up the audience's interest in watching films online. On the other hand, festival distributors need to inform filmmakers about different types of requirements for the festival submissions.

\section{Coordination of Online and Traditional Distribution Processes}

Distributors think it is impossible to create an effective film distribution system based only on the new media. There needs to be a coordination of traditional and online distribution processes. In this case, theatre distribution must be given first priority. Exhibiting halls should be made attractive and comfortable for all kinds of audiences by upgrading and improving the environment. Theatres should be air-conditioned, the seats should be comfortable, screening quality and the sound system should be up to the mark. There needs to be a food court and other conveniences to ensure that the audience is being provided complete entertainment. Again, the number of theatres should be increased. Moreover, theatres can adopt a strategy first introduced by the American company, "MoviePass" (founded in 2011), which is called "Netflix for Theatres", allowing a subscriber to buy a movie ticket every day with a flat subscription fee for the whole month (Hardawar, 2012).

There should be a chain for film distribution. This means that, at first, the film will be released only in theatres, and then, after a specific period of time, the film would be available on online platforms with the pay-per-view payment mode or subscription mode and lastly, it would be shown on television channels. With this planned chain distribution, revenue will be generated from different platforms. For this type of coordination, efficient and robust leadership must develop. All these could be implemented successfully if it becomes possible to obstruct piracy using proper equipment to detect the guilty parties and sufficient involvement of law enforcement to ensure punishment.

Online film distributors also argued that the film production companies should develop their own online platforms like most Indian sites, such as Eros Now, Hungama, Jio Cinema etc. where all the films produced by one company will be available online after a certain period of theatre release, and the audience will be able to watch those films any time by paying a subscription fee.

\section{Working at the Policy Level}

Work needs to be done at the policy level to establish an effective distribution system. The coordination of policies for online and traditional distribution is especially important here. Online content making policy should be decided based on Bangladeshi social values and cultural norms. For example, BongoBD uploaded a music video Nesha sung and performed by Kushum Shikder on its YouTube channel, which was accepted by the YouTube authority as it did not get flagged in conflict with YouTube's content policy. However, after the video was released, a Supreme Court lawyer filed a legal notice to remove the music video from all 
social media outlets, claiming that it falls under section eight of the Pornography Act 2012. The, the global policy may not be applicable to Bangladesh.

Distribution of revenues in case of online distribution and ticket pricing in traditional distribution should be determined by the government. Real box office information should be available online, which will help the producers to understand how the audience is responding to their films and this will help to improve the quality of the content in the long run.

A policy should be implemented to help improve the environment of the cinema theatres. For example, if anyone wants to import chairs to replace the old chairs in the movie theatre, they would have to pay a 37.07\% tax (Bangladesh Customs: National Board of Revenue, 2018). Distributors suggest reducing the tax rates on importing theatre materials like the projector, chairs, air cooler, sound equipment etc. for a certain period of time, which will encourage the theatre owners to renovate the theatres.

The Producers and Distributors Association should be split into two associations. At present, a producer does not feel pressure to produce good films as they play the role of distributor for their own films as well. Having a separate distributor's association will help pressurize producers to make good films. On the other hand, The Producers and Distributors Association does not have an executive committee. As a result, there are no spokespersons to talk about the problems and policy development in the production and distribution sector. This gave rise to the monopoly of the booking agents as an intermediary force in the distribution system. The necessity of the executive committee can be proved through a real life example. When Jaaz Multimedia set up digital projectors in some theatres, it demanded that the distributors provide the rent for the projectors, when it is always the exhibitor's job to make arrangements for the projection. As a result, distributors had to spend extra money on the projectors till now, and no one was there to protest it. There is a dire need for separate executive committees for the separate associations of the producers and the distributors to get rid of these issues.

\section{Making Good Films}

There is no question that good films need to be made in order to attract the audience to both online and physical platforms of consuming films. To make good films, we need good artists. On the other hand, films should be made in accordance with the content making policies of online platforms, especially in cases of using original or copyright-free sound and music scores. Online streaming companies should invest in creating attention-grabbing websites, which is a must have from a global perspective to attract both foreign and local audiences.

\section{Discussion}

There are some key factors that contribute in the emergence of new media in the film distribution of Bangladesh. Three visibly prominent factors are: the rise of 
piracy, the decreasing number of cinema theatres and the domination of booking agents, which is supplementing the arrival of new technology and facilitating changes in the distribution pattern.

The rise of piracy made the gatekeepers of traditional cinema around the world think about a new form of film distribution. This was called online distribution which first began in 1997 in North America (Cunningham et al., 2010, p. 121), but in Bangladesh, Bongo initiated it 15 years later in 2012. Fair (2006) stated that digital technology is considered to have accelerated piracy as it is easier to make clones with very little loss of quality (Fair 2006, p. 30). But in Bangladesh, piracy in the CD and DVD format made the gatekeepers welcome new media in film distribution. However, the problem of piracy has not become rampant in the case of online content as it is just an emerging sector and distribution sites have not yet started making their own contents which could be pirated.

The number of theatres has decreased as only 321 were found open for business in 2016 (Roy, 2016), a number that was as high as 1,200 in 2005 (Hayder, 2012). One of the key reasons behind this was the scarcity of good content, led by the internal problems of the distribution system in the last decades of the $20^{\text {th }}$ century. In this system, there is an association for distributors, which is also the association for producers, as it is named Bangladesh Film Producers and Distributors Association (BFPDA). This kind of weak policy, which can be understood with the third basic characteristic of the critical political economy, created havoc not only in the distribution sector but also in the entire film industry. When the distributor and producer is the same person, there is no compulsion for the producer to create good films since he or she can distribute any film he or she wants. Again, the environment and the service of the still running theatres have started deteriorating, which will lead those to get shut down in the near future.

At present, the association (BFPDA) is under a government administrator as there is no elected executive committee. There is no active executive committee and distributors cannot participate in policymaking. As there are no spokespersons to negotiate the various types of policies with the state, the decision-making power is secured one-sidedly by the state only. Taking advantage of this loophole, booking agents grew as an intermediary force determining the fate of a film as they do not select films for theatres based on good content but the casting, the glamour factor etc. As a result, theatres lost their appeal to the audience, and the business became a financial loss for the owners, which led them to close their theatres down.

All these hindrances have led to the emergence of new media based online distribution. But the new opportunities came with new challenges too. Online film distribution has several advantages. Traditional distributors are starting online distribution and making it a part of their whole distribution process, which will thereby change the structure of these traditional distribution companies. The rise of the internet has advanced the opportunities for commodification where the commodification of goods and services means transforming good and services into commodities which are valued for what they earn in the marketplace (Mosco, 2009, p. 11). Mosco (2009) found digital technology changing the structure of existing 
companies (Mosco, 2009, p. 15) where online distribution has commodified films as it enabled films to reach their audience directly, providing them the opportunity to watch the film whenever they like in exchange for the money taken as a subscription fee. Pendakur (1990) espoused the same idea by describing the film as a "tangible product and intangible service" (Pendakur, 1990, p. 39).

This kind of flexible service promoted by new media technology is significant as it is changing the models of earning revenue. In case of theatre distribution, the generated revenue is distributed among several groups of people such as, the producer, the distributor, the booking agent and the exhibitor. But online distribution operates by sharing revenue only between the content provider and the distributor. As Zhu (2001) shows in his research, the distribution cost is reduced with the disintermediation in the motion picture value chain (Zhu, 2001, p. 275).

Spatialization, as in "the process of overcoming the constraints of space in social life" (Mosco, 2009, p. 14), encompasses the process of globalization, which is identified by Harvey (1989) as "time-space compression", suggesting the way the world is becoming smaller (Harvey, 1989, p. 149). Because of online film distribution, the audience need not go to the theatres, commuting to which consumes valuable time in big cities like Dhaka and Chittagong due to excessive traffic jam. Moreover, audiences from different parts of the world are now able to watch Bangladeshi films whenever and wherever they want.

Again, privatization and liberalization of telecommunications services have created the opportunity for free market by providing the telecommunications companies the chance to create online distribution platforms as most of the OLD platforms in Bangladesh are owned and controlled by these telecommunications companies.

But this coin has a flip side as well. Wasco (2014) emphasizes the assessment of media power by the discussion of class issues (p. 263). The internet can become a powerful medium of film distribution, but it is limited to the people of an economic class who can afford to buy a device like a smartphone, tablet, or personal computer and have access to the high-speed internet where most of the people in Bangladesh do not have access to the internet with minimum speed (Bangladesh Telecommunication Regulatory Commission, 2019). This is an image of inequality because most of the people in Bangladesh are not able to access the internet. Again, inconsistency is found in the legislation as there is no specific policy for VOD services, but traditional films have to pass through the sensor board before being released.

Mosco (2009) describes social totality as understanding the society with a holistic approach from economic, political, social, and cultural perspectives (Mosco, 2009, p. 3) and especially the connections between the political and the economic (Mosco, 2009, p. 29). Traditional distribution and online distribution generate different social cultures. People go to watch cinema in theatres in their leisure time, maybe with family and friends, eat food, go shopping etc. It becomes an avenue for get-togethers, which strengthens social bonds. However, online film distribution encourages an individualistic culture where one can watch any film they wish in their free time. It works to loosen the social bond. 
New media involve a significant change in social and economic relations (Mansell, 2004, p. 7). According to Wasko (2014), power relations can be analyzed by identifying the owners and controllers of online distribution outlets (p. 260). In Bangladesh, online distribution sites like Bioscope and Iflix are streaming as video platforms of telecommunications companies like Grameenphone of Telenor, a Norwegian multinational telecommunications company, and Robi Axiata Limited of Axiata Group, a Malaysian telecommunications company. Bioscope is run by BongoBD, which is the only emerging multinational subscription-based VOD service provider that originated in Bangladesh. BongoBD is now focusing on upgrading Bioscope as it uses Grameenphone as a payment gateway. Iflix is a subscription-based Malaysian VOD service, which is also attached to Robi Axiata Limited to have it as a payment gateway.

So, there are two types of controllers of the leading online film distribution companies in Bangladesh: telecommunications companies and multinational foreign and native VOD service provider companies. In case of Iflix and BongoBD, owners are multinational companies, and in the case of Bioscope, the owner is a telecommunications company. However, in every case, there is a telecommunications company as distribution companies need to make use of them as payment gateways. In addition to this, the telecommunications companies are trying to take control over the online distribution. Mahbub (2016) indicates that there is a silent war going on among the major telecom operators in Bangladesh for the control of digital service space. As foreign multinational companies are mostly investing in the sector, global capital is absorbing the local market here.

On the other side, BongoBD, the only Bangladeshi online platform, is also targeting to expand into the global market. Ahsan (2012) claims that there are active audiences for Bangladeshi films in different parts of the world. The term 'active audience' is defined by Kehoe and Mateer (2015) as the "emergence of a new group of technology-savvy consumers who primarily consume media product via the Internet" (Kehoe and Mateer, 2015, p. 99). Here, local capital is entering into a foreign market, changing the direction of the flow of media materials. Bhuiyan (2002) makes a relevant comment about the expansion of multinational capital and says that it has altered the direction of global and regional flows of media materials (Bhuiyan, 2002, p. 120).

On the other hand, festival distributors, Khona Talkies and Indi Minds are basically owned and controlled by independent filmmakers. They started this type of distribution to participate in different film festivals with their own films, and later transformed into business platforms.

A critical situation prevails in the distribution sector of the Bangladesh Film Industry. Distributors are economically endangered, and online distribution is perceived by them as a gateway to earn some additional revenue which led them to taking it positively. They suggest that a coordination of traditional and new mediabased film distribution process take place. This has been described by Mosco (2009) who states that flexible companies make changes to the relationships with other companies by using communication and information systems like internet (Mosco 2009, p. 15). 


\section{Conclusion}

This research tried to explore the present situation of new media based film distribution in Bangladesh. It tried to see how it affected the traditional film distribution system and tried to develop a framework for an effective distribution system. This research was conducted based on in-depth interviews of people involved in the traditional distribution system and new media-based distribution system.

Online film distribution is a growing sector in Bangladesh. Piracy, decreasing number of cinema theatres, increasing demand of Bangladeshi content in different areas of the world, less expense in online distribution, the production of alternative cinemas, and the urge to participate in different film festivals around the world made distributors start using internet technologies in film distribution. At present, the sector is controlled by telecommunications companies. Most of the sites started out as value-added services of the mobile network operators with a view to creating video streaming platforms and controlling the digital service space in Bangladesh. Even though some take the online distribution as a threat to theatrical distribution, the greater part of the traditional film distributors perceives online distribution as supportive to the film distribution system as it diminishes the cost of film distribution by disintermediating booking agents and exhibitors from the distribution process and increases revenue. A coordination between traditional and online film distribution needs to be facilitated to create an effective film distribution system, where the making of good films and working at the policy level are essential.

\section{Limitations}

It was challenging to find out the effects of new media in film distribution, as most of the traditional distributors had a hard time expressing their thoughts. Additionally, only ten distributors were interviewed for the research. It would be better to interview more traditional and online film distributors. Again, some YouTube based distributors could have been vital as respondents for the research, but it was not possible to interview them as they were unavailable during the data collection phase. Moreover, the research has not included audience perception about the new media-based film-watching platforms. If the opinion of the audience could be analyzed, the research would be more comprehensive. On the other hand, the research did not include the marketing strategy of online film distribution, which seems necessary for a better understanding of the sector. The absence of previous studies in this sector in Bangladesh also made this research very challenging.

\section{Future Areas of Research}

Future researchers can study the following aspects. First, the researchers can assess the audience perception of online media as a cinema watching platform in Bangladesh. Second, research can be done on the marketing strategies of online 
distributors to understand the changing trends of film marketing in the era of new media. Finally, a comprehensive study on the whole film distribution system of Bangladesh can be done to understand the roles of stakeholders in developing an effective film distribution system.

\section{Acknowledgements}

I am grateful to Dr. A. J. M. Shafiul Alam Bhuiyan, Professor, Department of Television, Film and Photography, University of Dhaka, for his encouragement, guidance, and for the excellent suggestions he made upon appraising the drafts. Thanks to the Athens Institute for Education and Research for allowing to modify the template they have developed.

\section{References}

Ahmed, S. (2010). New media marketing of bollywood movies: making a difference. Proceedings of the Conference of Comunicacao em Debate, 545-553. Avanca, Portugal.

Ahsan, M. S. (2012). Integration of digital technology in the film industry of bangladesh: readiness and response functions. Doctoral Dissertation. Manchester, United Kingdom: The University of Manchester.

Ahsan, M. S. (2016). Impacts of funding in digitising the Bangladesh Film industry: challenges ahead. South Asian Popular Culture, 14(3), 241-248.

Bangladesh Customs: National Board of Revenue (2018). Duty calculator. Retrieved from: http://www.bangladeshcustoms.gov.bd/trade_info/duty_calculator. [Accessed 15 June 2018]

Bangladesh Film Producers and Distributors Association (2018). Members. Retrieved from: http://filmproducersassociation.com.bd/index.php/welcome/Members.aspx. [Accessed 9 February 2018]

Bangladesh Telecommunication Regulatory Commission (2019). Internet subscribers. Retrieved from http://www.btrc.gov.bd/content/internet-subscribers-bangladesh-feb ruary-2019. [Accessed 7 October 2020]

Bhuiyan, A. J. (2002). The political economy of mass communication in Bangladesh. The Journal of International Communication, 8(2), 118-136.

Bordwell, D., Thompson, K. (2008). Film art: an introduction. $8^{\text {th }}$ Edition. New York: McGraw-Hill.

Cunningham, S., Silver, J., McDonnell, J. (2010). Rates of change: online distribution as disruptive technology in the film industry. Media International Australia, 136(1), $119-132$.

Fair, J. (2006). The impact of digital technology upon the filmmaking production process. Master Thesis. Dublin, Ireland: University College Dublin.

Guback, T. H. (1969). The international film industry: Western Europe and America since 1945. Bloomington: Indiana University Press.

Hardawar, D. (2012). Venture beat. MoviePass debuts an unlimited movie service that may just save cinemas. Retrieved from: https://venturebeat.com/2012/10/02/movie pass-theater-subscription-service/. [Accessed 29 April 2018]

Harvey, D. (1989). The Condition of Postmodernity. Oxford: Blackwell. 
Hayder, K. M. (2012). Prekkhagriho bondher michil. (Cinema theatres closing down at an alarming rate). Magic Lanthan, 1(2), 1-13.

Hossain, D. M. (2017). Poribeshon o prodorshon poddhotie Bangladesher cholochchitrer unnoyoner prodhan ontoray. (The system of distribution and exhibition is the main obstacle to the development of cinema in Bangladesh). Bangladesh Cinema and Television Institute Journal, 1(5), 59-75.

Kareem, S. S. (2017). Film distribution process in Bangladesh: Loopholes and suggestions for establishing an effective distribution system. IOSR Journal of Humanities and Social Science, 22(12), 57-62.

Kehoe, K., Mateer, J. (2015). The impact of digital technology on the distribution value chain model of independent feature films in the UK. International Journal on Media Management, 17(2), 93-108.

Khan, A. R. (2017). Cholochchitrer poribeshonay buddhibrittik shunnota ebong uttoroner somvabbo upay. (Intellectual vacuum in film distribution and possible ways to resolve this problem). Magic Lanthan, 7(13), 74-85.

Kozlowski, L. (2012). The future of film. Forbes. Retrieved from: https://www.forbes.co m/sites/lorikozlowski/2012/08/03/the-future-of-film/\#7d96643579d2. [Accessed 29 September]

Lister, M., Dovey, J., Giddings, S., Grant, I., Kelly, K. (2009). New media: a critical introduction. $2^{\text {nd }}$ Edition. New York: Routledge.

Mahbub, I. (2016). GP quietly launched video streaming service bioscope. Future Startup. Retrieved from: https://futurestartup.com/2016/09/18/gp-quietly-launched-video-stre aming-service-bioscope/. [Accessed 13 May 2018]

Mansell, R. (2004). Political economy, power and new media. New Media \& Society, 6(1), 96-105.

Mosco, V. (2009). The political economy of communication. London: Sage Publications Ltd.

Murdock, G., Golding, P. (2005). Culture, communications and political economy. In J. Curran, M. Gurevitch (eds.), Mass Media and Society, 60-83. London: Hodder Arnold.

Neese, B. (2016). What is new media. Southeastern University Online Learning. Retrieved from: http://online.seu.edu/what-is-new-media/. [Accessed 9 March 2018]

Nime, N. M. (2012). The impact of digital technology on documentary distribution. British Library-EThOS e-Thesis Online Service. Retrieved from: http://ethos.bl.uk/OrderDe tails.do?uin=uk.bl.ethos.589008. [Accessed 9 March 2018]

Parks, S. (2007). The insider's guide to independent film distribution. Waltham, Massachusetts: Focal Press.

Parvez, R. (2013). Porobeshon o prodorshon bebosthar halchal: Uttorone projashokoler ghumonto chinta. (The state of film distribution and exhibition system: The peasants' slumbering thoughts to a resolution). Magic Lanthon, 2(4), 1-8.

Pendakur, M. (1990). Canadian dreams and American control: the political economy of the Canadian film industry. Detroit: Wayne State University Press.

Roy, N. (2016). The death of cinemas in Bangladesh. Dhaka Tribune. Retrieved from: http://www.dhakatribune.com/bangladesh/2016/04/23/death-cinemas-bangladesh/. [Accessed 10 May 2018]

Wasko, J. (2004). The political economy of film. In T. Miller, R. Stam (eds.), A Companion to Film Theory, 221-233. Malden: Blackwell Publishing Ltd.

Wasko, J. (2014). The study of the political economy of the media in the twenty-first century. International Journal of Media \& Cultural Politics, 10(3), 259-271.

Zhu, K. (2001). Internet-based distribution of digital videos: the economic impacts of digitization on the motion picture industry. Electronic Markets, 11(4), 273-280. 
